\title{
Antibacterial Diterpenoid Against Pathogenic Oral Bacteria of Streptococcus Mutans ATCC 25175 Isolated From Sarang Semut (Myrmecodia Pendans)
}

\author{
Mieke H. Satari ${ }^{1}$, Boima Situmeang ${ }^{2}$, Indah Permata Yuda ${ }^{2}$, Dikdik Kurnia ${ }^{2}$ \\ ${ }^{1}$ Department of Oral Biology, Faculty of Dentistry, Universitas Padjadjaran, \\ Jl. Raya Bandung-Sumedang km. 21, Sumedang, 45364, Indonesia \\ ${ }^{2}$ Department of Chemistry, Faculty of Mathematics and Natural Sciences, Universitas Padjadjaran, \\ Jl. Raya Bandung-Sumedang km. 21, Sumedang, 45364, Indonesia \\ *Corresponding author: dikdik.kurnia@unpad.ac.id
}

\begin{abstract}
Discovery of new antibacterial agent to treat oral disease caused by pathogenic oral bacteria is an attracted focus to more pay attention of researcher. The tropical natural product is the promising sources of new bioactive as antibacterial compounds. The epiphyte plant of Sarang Semut (M. pendans) empirically has been used as a drug to treat various diseases. Our previous research found that ethyl acetate extract of Sarang Semut inhibited the bacteria growth of Enterococcus faecalis. This study aims to isolate, structure determination and antibacterial activity evaluation of active compound against Streptococcus mutans ATCC 25175. The isolation by combination chromatography on normal and reverse phase resulted an antibacterial compound 1. Based on the analysis of the spectroscopic data including IR, FTIR, ${ }^{1} \mathrm{H}-\mathrm{NMR},{ }^{13} \mathrm{C}-\mathrm{NMR}, 2 \mathrm{D}-\mathrm{NMR}$ as well as by mass spectroscopic (MS) and compare to reported data, structure of compound $\mathbf{1}$ was suggested as terpenoid type diterpene derivative. Antibacterial activity evaluation by Kirby-Bauer method of compound $\mathbf{1}$ against $S$. mutans ATCC 25175 showed inhibition zone values were $17.8,14.5$ and $11.1 \mathrm{~mm}$ at 10000,5000 and 1000 ppm, respectively, while the MIC and MBC values were $18.125 \mathrm{ppm}$ with MBC of $2500 \mathrm{ppm}$, respectively.
\end{abstract}

Keywords: Sarang Semut, Myrmecodia pendans, Streptococcus mutans, pathogenic oral bacteria.

DOI:10.15408/jkv.v5i2.8864

\section{INTRODUCTION}

Dental caries is the most prevalent and costly oral infectious disease worldwide caused by pathogenic oral bacteria over 700 different bacterial species, especially of Streptococcus mutans that initiates the cariogenic processes, interact with dietary sugars to promote virulence and as a key virulence factor to establish cariogenic biofilms. Natural products offer a rich source of structurally diverse substances with a wide range of biological activities including antimicrobial agent of antibacterial and antifungal, which could be useful for the development of alternative or adjunctive anticaries therapies (Jeon et al., 2011; Zhang et al., 2017).

The epiphyte plant of Sarang Semut (Myrmecodia pendans) is endemic plant in Papua Island, located in eastern Indonesia and have a long history used by Papua community as a medicinal plant to treat various diseases including cancer, tumors, gout, diarrhea, fever and each other diseases (Soekmanto et al., 2010; Singh and Pandeya, 2011; Supriatno, 2014). M. pendans is a member of Rubiaceae family with 5 genus, however only two which association with ant. They are Myrmecodia (45 
species) and Hypnophytum (26 species) from those of species, only $H$. formicarum, $M$. pendans and $M$. tuberosa are considered to have medicinal values Soeksmanto et al., 2010).

Previous studies demonstrated that many bioactive constituents including antibacterial compounds have been isolated from medicinal plants. According to Sarang Semut, it was reported to have potential antibacterial-active phytochemical compounds and have been used empirically as natural medicine (Buang et al., 2013; Engida et al., 2013; Kusmoro, 2013). Previous paper reported that ethanol extract of Myrmecodia pendans has antibacterial activity against Escherichia coli, at a concentration of 25 and $50 \%$, and also has antibacterial activity against Shigella dysentriae and Klebisella pneumonia. Our previous research found that ethyl acetate extract of Sarang Semut can inhibit the growth of Enterococcus faecalis ATCC 29212, Streptoccus mutans ATCC 25175 and Phorphyromonas gingivalis ATCC 33277 (Widyawati et al., 2016; Alibasyah et al., 2017; Alibasyah et al., 2017; Gartika et al., 2018). The herbal medicines is one of the solutions to treat some infection disease caused by microorganism including of bacteria (Sulistiyaningsih et al., 2011; Roslizawati et al., 2013). As continuing our search for new bioactive compounds from Indonesia plant, in this paper describe the isolation, structure determination and antibacterial evaluation of active constituents from Sarang Semut against pathogenic oral bacteria of Streptoccus mutans ATCC 25175 (Hasanudin et al., 2015; Malinda et al., 2016; Kurnia et al., 2017).

\section{MATERIALS AND METHODS Materials}

Sample of Sarang Semut (Myrmecodia pendans) was collected on June 2015 from Papua, Indonesia. The specimen was determined and deposited (No. MP - 034) at Laboratory of Plants Taxonomy - Department of Biology, Faculty of Mathematics and Natural Science Universitas Padjadjaran, Bandung, Indonesia. Kiesel G 60 silica gel resins and the ODS of LiChroprep RP-18 (Merck, Darmstadt, Germany), were used for column chromatography. TLC analysis was carried out using Kiesel gel $60 \mathrm{~F}_{254}$ and RP-18 $\mathrm{F}_{254 \mathrm{~S}}$ (Merck) reacted with spraying of $10 \%$ $\mathrm{H}_{2} \mathrm{SO}_{4}$-ethanol reagent followed by heating at $100^{\circ} \mathrm{C}$ for $1-2 \mathrm{~min}$. Deuterated solvents were purchased from Merck Co. Ltd. and Sigma Aldrich Co. Ltd. (St. Louis, MO, USA).

\section{Instruments}

NMR spectra recorded on a $500 \mathrm{MHz}$ FT-NMR spectrometer (Varian ECA 500 JOEL, Japan). IR spectra were obtained from a Perkin Elmer Spectrum One FT-IR spectrometer (Buckinghamshire, England). MIC and MBC were measured on Biochrom Ez Read 400 Elisa Reader. Laminar airflow, incubator Memmert, autoclave machine HVE50 Hirayama, and jar for antibacterial activity assay.

\section{Test Organisms}

Streptococcus mutans ATCC 25175 were used for antibacterial test on Muller Hinton broth and Muller Hinton agar as medium, chlorhexidine, (were purchased from Merck Co. Ltd. and Sigma Aldrich) as positive control, and anaerobic jar (for anaerobic condition) for antibacterial assay.

\section{Preparation of Extract}

The freshly sample of Sarang Semut (M. pendans; $1.5 \mathrm{~kg}$ ) were cutting into small pieces (i.d $\pm 1 \mathrm{~cm}$ ) and of $300 \mathrm{~g}$ was soxhleted with ethyl acetate in 2x6 hours for five times, repeatedly. The extract was filtered and evaporated in vacuo at $40{ }^{\circ} \mathrm{C}$ to give a residue of $15 \mathrm{~g}$.

\section{Antibacterial Activity of Compound 1}

Antibacterial activity of compound 1 against Streptococcus mutans ATCC 25175 used in this study was conducted using disk diffusion (CLSI, 2012). The Kirby-Bauer disk diffusion susceptibility test was used to determine the sensitivity or resistance of $S$. mutans ATCC 25175 to compounds. The procedure was according to reference in CLSI protocols (CLSI, 2012). Compounds were diluted with methanol-water $(1: 1)$, however chlorhexidine (positive control) were diluted with water. All of samples and controls were performed out of concentration 1 and $5 \mu \mathrm{g} / \mathrm{mL}$. Paper discs $(7 \mathrm{~mm})$ were impregnated with 20 $\mu \mathrm{L}$ of each sample and then discs loaded with compounds were placed onto the surface of the agar. Tests were performed in duplicates.

The MIC and MBC activities of compounds $\mathbf{1}$ and references of antibiotics against $S$. mutans ATCC 25175 were determined by micro-dilution method in 96well micro plates (CLSI, 2012). The bacterial 
cells were pre-cultured in Muller Hinton broth at $37{ }^{\circ} \mathrm{C}$ under aerobic conditions and incubated in the presence of compounds with the concentrations obtained by serial two-fold dilution at $37{ }^{\circ} \mathrm{C}$ without shaking in the same broth for $24 \mathrm{~h}$ on micro and their MICs were estimated as the lowest concentrations where the bacterial cells were not observed visually as reported previously, and given based on triplicate experiments. Water or methanol used for dissolving compounds that of water and methanol have no effect to bacterium. The positive control, chlorhexidine, fosfomicyn and amoxciciline were dissolved in water and the tests were performed in duplicate.

\section{Isolation of Antibacterial Compound 1 From Ethyl Aceate Extract of Sarang Semut (M. Pendans)}

The ethyl acetate extract (15 g) was chromatographed on silica G 60 (70-320 mesh) eluted with $n$-hexane-ethyl acetate (90:10-10:90 step wise) to resulted eleven fractions. The fraction 5 was then subsequently chromatographed on silica gel G 60 ( $n$-hexana:ethyl acetate; 5:5 v/v) and on ODS RP-18 (8:2 v/v), respectively, and gave compound 1 (130 mg).

\section{RESULTS AND DISCUSSION Isolation and Structure Determination of Compound 1}

Antibacterial compound from ethyl acetate extract of Sarang Semut (M. pendans) was isolated by bioactivity-guided chromatography separation using combination on normal and reverse phase with various solvents polarity. The purification of active constituents was checked by thin layer chromatograpghy on Silica G $60 \mathrm{~F}_{254}$ and ODS RP-18 with observed on UV at $\lambda_{\max } 254$ and $365 \mathrm{~nm}$, and reacted with coloring reagent of $\mathrm{H}_{2} \mathrm{SO}_{4}(10 \%$ in ethanol) to give dark spots and revealed compound $\mathbf{1}$, then the structure was elucidated by analysis of its spectroscopic data including FT-IR, NMR and MS.

Table 1. NMR data of compound 1 (500 Mhz for ${ }^{1} \mathrm{H}$ and $125 \mathrm{Mhz}$ for ${ }^{13} \mathrm{C}$, In $\mathrm{CD}_{3} \mathrm{OD}$ )

\begin{tabular}{cccc}
\hline Position & ${ }^{13} \mathbf{C}-\mathbf{N M R} \boldsymbol{\delta}_{\mathbf{C}}(\mathbf{p p m})$ & ${ }^{\mathbf{1}} \mathbf{H}-\mathbf{N M R} \boldsymbol{\delta}_{\mathbf{H}}(\mathbf{I n t} ., \mathbf{m u l t} . \mathbf{J} \mathbf{J = H z})$ & HMBC $^{\mathbf{1}} \mathbf{H}$ to ${ }^{\mathbf{1 3}} \mathbf{C}$ \\
\hline 1 & 39.4 & $2.55(2 \mathrm{H}) ; m$ & $\mathrm{C}-2,9$ \\
2 & 24.0 & $1.24(2 \mathrm{H}) ; m$ & $\mathrm{C}-5,3$ \\
3 & 78.9 & $4.26(1 \mathrm{H}) d d ; 6.5 ; 10.0$ & $\mathrm{C}-1$ \\
4 & 39.5 & - & - \\
5 & 32.5 & $3.64(1 \mathrm{H}) ; m$ & - \\
6 & 33.1 & $1.23(2 \mathrm{H}) ; m$ & $\mathrm{C}-10$ \\
7 & 42.3 & $1.95(2 \mathrm{H}) ; m$ & - \\
8 & 148.5 & - & - \\
9 & 26.1 & $2.74(1 \mathrm{H}) ; m$ & - \\
10 & 48.6 & $2.93(1 \mathrm{H}) ; m$ & - \\
11 & 118.7 & $4.95(1 \mathrm{H}) ; m$ & - \\
12 & 136.5 & - & - \\
13 & 71.2 & - & - \\
14 & 42.6 & $1.96(1 \mathrm{H}) ; m$ & $\mathrm{C}-16,14,13$ \\
15 & 29.2 & $1.15(3 \mathrm{H}) ; d ; 1.95$ & $\mathrm{C}-15,14,13$ \\
16 & 29.2 & $1.16(3 \mathrm{H}) ; d ; 1.95$ & $\mathrm{C}-8$ \\
17 & 114.4 & $4.54(2 \mathrm{H}) ; m$ & - \\
18 & 14.7 & $0.9(3 \mathrm{H}), t ; 7.15 ; 13.0$ & - \\
19 & 13.1 & $1.2(3 \mathrm{H}), m$ & $\mathrm{C}-12$ \\
20 & 177.1 & - & $\mathrm{C}-20$ \\
20 & 17.1 & $1.5(3 \mathrm{H}) ; s$ & \\
\hline
\end{tabular}


The compound 1 was obtained as oily form and soluble in methanol. The IR spectrum of compound $\mathbf{1}$ showed absorptions peaks at 3400,1688 , and $655 \mathrm{~cm}^{-1}$ for hydroxyl, carbonyl and olefinic functional groups (Keat et al., 2010; Uddin et al., 2011), together with signals of $\mathrm{C}-\mathrm{H}$ bending and gem dimethyl stretching at 1456 and $1374 \mathrm{~cm}^{-1}$, respectively (Bababola and Shode, 2013). ${ }^{13}$ C-NMR, DEPT $135^{\circ}$ and ${ }^{1} \mathrm{H}-\mathrm{NMR}$ spectra of compound $\mathbf{1}$ indicated signals for twenty one carbons including five methyls, five methylenes, six methynes and five quaternary carbons as shown in Table 1.

In order to determine the structure of 1, further spectroscopic analysis was conducted by measurement 2D NMR of ${ }^{1} \mathrm{H}$ COSY, HMQC and HMBC of 1. From the 2D NMR spectra, the connectivity of carbonscarbons and carbons-protons were observed and evaluated to predict of detail structure.

From the HMBC spectrum those indicating connectivity signals of proton to carbons showed the correlation peaks of $\mathrm{H}-1$ $\left(\delta_{\mathrm{H}} 2,5 \mathrm{ppm}\right)$ with C-2 and C-9; H-2 $\left(\delta_{\mathrm{H}} 1,2\right.$ ppm) with C-5, C-2 and C-3; H-3 $\left(\delta_{\mathrm{H}} 2,5 \mathrm{ppm}\right)$ with $\mathrm{C}-1$, and $\mathrm{H}-3\left(\delta_{\mathrm{H}} 4,2 \mathrm{ppm}\right) \mathrm{C}-1$. Other signals were indicated connectivity between $\mathrm{H}$ $6\left(\delta_{\mathrm{H}} 1,2 \mathrm{ppm}\right)$ with $\mathrm{C}-10 ; \mathrm{H}-15\left(\delta_{\mathrm{H}} 1,1 \mathrm{ppm}\right)$ with $\mathrm{C}-16$ and $\mathrm{C}-14 ; \mathrm{H}-16\left(\delta_{\mathrm{H}} 1,1 \mathrm{ppm}\right)$ with $\mathrm{C}-15$ and C-14, C-13. Further analysis also observed correlation peaks of $\mathrm{H}-17\left(\delta_{\mathrm{H}} 4,5\right.$ ppm) with C-8; H-19 ( $\left.\delta_{\mathrm{H}} 1,2 \mathrm{ppm}\right)$ with C-20 and C-3; and $\mathrm{H}-20^{\prime}\left(\delta_{\mathrm{H}} 1,5 \mathrm{ppm}\right)$ with C-4, C-5 and $\mathrm{C}-20$. Detail analysis of all spectroscopic data, suggested that the suggested structure of 1 as terpenoid type diterpen of labdane derivative as seen in Figure 1 (Roh et al., 2010; Souza et al., 2011; Patra et al., 2015). The structure was determined by the analysis of NMR data as well as by comparison with previously reported values (Filho et al., 2002).

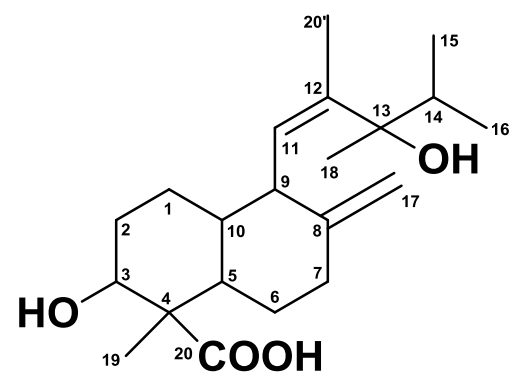

Figure 1. Structure terpenoid type diterpene of compound 1
The compound $\mathbf{1}$ suggested as a terpenoid type diterpene derivative isolated from Sarang Semut (M. pendans) and published for the first time in this report.

\section{Antibacterial Activity of Compound 1}

Evaluation for antibacterial activity of compound $\mathbf{1}$ was conducted by tested against pathogenic oral bacteria of Streptococcus mutans ATCC 25175 using Kirby-Bauer methods for inhibition zone values. The result showed that compound $\mathbf{1}$ was inhibit the bacterial growth after $48 \mathrm{~h}$ incubation in Mueller Hilton agar plates with values of 17.8, 14.5 and $11.1 \mathrm{~mm}$ at 10000,5000 and 1000 ppm, respectively. Compared to chlorhexidine as positive control at $1000 \mathrm{ppm}(14.6 \mathrm{~mm})$, the compound 1 was less active than controls. For further analysis of antibacterial activity of $\mathbf{1}$, the MIC and MBC values against $S$. mutans 25175 were determined according to CLSI protocols. As the result, MIC and MBC values of 118.125 and $1250 \mathrm{ppm}$, respectively which indicated that compound $\mathbf{1}$ had capacity to inhibit the growth of pathogenic bacteria of $S$. mutans. This data according to Clinical Laboratory Standard International protocol's, the categories of susceptibility on bacteria was shown inhibition zone using Kirby-Bauer method as follow susceptible $(\leq 20 \mathrm{~mm})$, intermediate $(15-19 \mathrm{~mm})$ and resistant $(\geq 14$ $\mathrm{mm}$ ) (CLSI, 2012). Many terpenoids have been reported to have many bioactivities including antimicrobial agent, as showed in previously reported that triterpenoid compounds of amyrin, ursolic acid, and betulinic acid were published has many antibacterial and antimicrobial activity (Daisy et al., 2008; Saha et al., 2011; Wang et al., 2012; Wang et al., 2013). The finding from this study supported previous reported data for terpenoids groups as one of bioactive constituents as antibacterial agent in medicinal plant of Sarang Semut ( $M$. pendans) (Kurnia, 2017).

\section{CONCLUSION}

The infection oral disease caused by pathogenic oral bacteria is one of the special attention for researcher focused in drug discovery of natural product. The study in continuing search and discovery new bioactive antibacterial agent from epiphyte plant of Sarang Semut (M. pendans) showed that the ethyl acetate extract contained an antibacterial 
diterpenoid (1) which active against $S$. mutans 25175 with inhibition values was as susceptible criteria. This study resulted the finding of good potency information data the use of this plant as source for new antibacterial drugs and phytomedicine for pathogenic oral disease.

\section{ACKNOWLEDGMENTS}

We gratefully acknowledge to Universitas Padjadjaran for Academic Leadership Grant 2017 and Riset Kompetensi Dosen Unpad (RKDU) Grant 2017.

\section{REFERENCES}

Alibasyah ZM, Purba A, Setiabudiawan B, Adhita HD, Kurnia D, and Satari MH. 2017. The efficacy of Sarang Semut extract (Myrmecodia pendens Merr \& Perry) in inhibiting Porphyromonas gingivalis biofilm formation. Dental Journal (Majalah Kedokteran Gigi). 50(2): 55-60.

Alibasyah ZM, Purba A, Setiabudiawan B, Hendra, Adhita HD, Kurnia D, Satari MH. 2017. The effectiveness of flavonoid and terpenoid isolate Sarang Semut (Myrmecodia pendens Merr and Perry) against Phorphyromonas gingivalis ATCC 33277. International Journal of Development Research. 07(07): 1355713561.

Babalola IT and Shode FO. 2013. Ubiquitous Ursolic Acid: A potential pentacyclic triterpene natural product. Journal of Pharmacognosy and Phytochemistry. 2(2): 214-222.

Buang Y, Noya E, Ola PD, Cunha TD. 2013. Antioxidant activities of chloroform and aqueous fractions of Myrmecodia Pendens extract: A preliminary study. Journal of Applied Chemical Science. 2(1): 187-195

Clinical and laboratory standards institute (CLSIformerly NCCLS). 2012. Performance standards for antimicrobial disk susceptibility tests; Approved standard, $11^{\text {th }}$ ed.; Clinical and laboratory standards institute: Wayne, PA, USA.

Clinical and Laboratory Standards Institute document M7-A8. 2012. Methods for dilution antimicrobial susceptibility tests for bacteria that grow aerobically; Approved standard, $9^{\text {th }}$ ed.; Clinical and laboratory standards institute: Wayne, PA, USA.

Daisy P, Mathew S, Suveena S, Rayan NA. 2008. A Novel Terpenoid from Elephantopus Scaber-Antibacterial Activity on Staphylococcus aureus: A Substantiate Computational Approach. International journal of Biomedical Science. 4(3): 196203.

Engida AM, Kasim NS, Tsigie YA, Ismadji S, Huynh LH, Jua YH. 2013. Extraction, identification and quantitative HPLC analysis of flavonoids from Sarang Semut (Myrmecodia pendan). Industrial Crops and Products. 41: 392-396.

Filho ER, Magnani RF, Xie W, Mirocha CJ, Pathre SJ. 2002. Hidroxilation of Labdane Diterpene Capresic acid by Fusarum graminearum. J. Braz, Chem. 13(2): 266269

Gartika M, Pramesti HT, Kurnia D, Satari MH. 2018. A terpenoid isolated from Sarang Semut (Myrmecodia pendans) bulb and its potential for the inhibition and eradication of Streptococcus mutans biofilm. BMC Complementary and Alternative Medicine. 18:151.

Hasanuddin, Krisnadi SR, Gandamihardja S, Kurnia D, Dharsono HDA. 2015. Terpenoid bioactive compound isolated from Papua ant nest induces the apoptosis of human ovarian cell lines (SKOV-3) and increasing caspase-9 activity. American Journal of Research Communication. 3(9): 2325-4076.

Jeon JG, Rosalen PL, Falsetta ML, Koo H. 2011. Natural Products in Caries Research: Current (Limited) Knowledge, Challenges and Future Perspective. Caries Res. 45(3): 243-263.

Keat NB, Umar RU, Lajis NH, Chen TY, Li TY, Rahmani M, Sukari. 2010. Chemical constituents from two weed species of Spermacoce (Rubiaceae). The Malaysian Journal of Analytical Sciences. 14(1): 6116.

Kurnia D, Sumiarsa D, Dharsono HDA, Satari MH. 2017. Bioactive compounds isolated from Indonesian epiphytic plant of Sarang Semut and their antibacterial activity against pathogenic oral bacteria. Natural 
Product Communications. 12(8): 12011204.

Kusmoro J, 2013. Lembar Identifikasi Tumbuhan. Laboratorium Taksonomi Tumbuhan, Jurusan Biologi UNPAD. Jatinangor.

Malinda Y, Satari MH, Tarawan VM, Kurnia D. 2016. Antibacterial of flavonoids from Myrmecodia pendens (Sarang Semut) against Streptococcus mutans ATCC 25175. Open Access Journal of Medicinal and Aromatic Plants (OAJMAP). 7(2): 110.

Patra JK, Kim ES, Oh K, Kim HJ, Dhakal R, Kim Y, Baek KH. 2015. Bactericidal effect of extracts and metabolites of Robinia pseudoacacia L. On Streptococcus mutans and Porphyromonas gingivalis causing dental plaque and periodontal inflammatory diseases. Molecules. 20: 6128-6139.

Roh SS, Park KM, Kim Y. 2010. Abeitic acid from Resina pini of Pinus Species as a Testosteron 5a-Reductase inhibitor. $J$ of health science, 56, 4, 451-455.

Roslizawati, Ramadhan NY, Fakrurrazi, Hernialtian. 2013. Antibacterial activity of ethanol extract and stew of antplant (Myrmecodia sp.) against Bacteri E. coli. Medika Valeninaria. 7(2): 0853-1915.

Saha S, Subrahyaman E, Kodangala C, Shastry S. 2011. Isolation and characterization of triterpenoids and fatty acid ester of triterpenoid from leaves of Bauhinia varagata. Der Pharma Chemica. 3(4): 2837.

Singh GS, and Pandeya SN. 2011. Natural product in discovery of potential and safer antibacterial agent. Natural product in medicinal chemistry. 63(101): 978-81-3080448-4.

Soeksmanto A, Simanjuntak P, Subroto MA. 2009. Uji toksisitas akut ekstrak air sarang semut (Myrmecodia pendans) terhadap histologi organ hati mencit. J. Nature Indonesia. 12(2): 152-155.

Soeksmanto A, Subroto MA, Wijaya H, Simanjuntak P. 2010. Anticancer activity for extracts of Sarang Semut plant (Myrmecodia pendens) to HeLa and
MCM-B2 Cells. Pakistan J. Biol. Sci. 13: 148-151.

Souza AB, Souza MGM, Moreira MA, Moreira MR, Furtado NAJC, Martins CHG, Bastos JK, Santos RA, Heleno VCG, Ambrosio SR, Veneziani RCS. 2011. Antimicrobial evaluation of diterpenes from Copaifera langsdorffii Oleoresin against periodontal anaerobic bacteria. Molecules. 16: 96119619.

Sulistiyaningsih, Kusima S, Wira A. 2011. Proceedings of the $2^{\text {nd }}$ International Seminar on Chemistry. 397-400: 978-60219413-1-7.

Supriatno. 2014. Antitumor activity of Papua's Myrmecodia pendens in human oral tongue quamous cell carcinoma cell line through induction of cyclin-dependent kinase. J Cancer Res Ther. 2(3): 48-53.

Uddin G, Waliullah, Siddiqui B, Alam M, Sadat A, Ahmad A, Uddin A. 2011. Chemical Constituents and Phytotoxicity of Solvent Extracted Fractions of Stem Bark of Grewia optiva Drummond ex Burret. J. Sci. Res. 8(1): 85-91.

Wang XY, Tang GH, Yuan CM, Zhang Y, Hou L, Zhao Q, Hao XJ, He HP. 2012. Two new tirucallane triterpenoids from Aphanamixis grandifolia. Nat. Prod. Bioprospect. 2: 222-226.

Wang XY, Tang GH, Yuan CM, Zhang Y, Zou T, Yu C, Zhao Q, Hao XJ, He HP. 2013. Aphagrandinoids A-D, cycloartane triterpenoids with antibacterial activities from Aphanamixis grandifolia. Fitoterapia. 85: 64-68.

Widyawati, Yanwirasti, Djong DH, Adhita HD, Kurnia D, Satari MH. 2016. Potential of terpenoid isolated from Myrmecodia pendans as antibacterial against Streptococcus mutans ATCC 25175. International Journal of Development Research. 06(11): 10350-10354.

Zhang Q, Nijampatman B, Hua Z, Nguyen T, Zou J, Cai X, Michalek SM, Velu SE, Wu H. 2017. Structure-Based Discovery of Small Molecule Inhibitors of Cariogenic Virulence. Scientific Reports. 7: 5974. 